\title{
Effective perioperative scoring in orthopedic surgery to prevent Covid-19 infection
}

\author{
Komang Agung Irianto ${ }^{1^{*}}$ and Taufan Adityawardhana ${ }^{2}$
}

\begin{abstract}
\section{BACKGROUND}

The pandemic has placed health-care workers (HCW) under an unprecedented strain where surgeries are being delayed and health care workers' deaths because of COVID-19 are prominent and causing staff shortages. An effective, fast, and concise approach to preoperative screening is very much needed. Hospitals are suggested to develop their own algorithm to minimize delays and complications. The objective of this study was to optimize HCW safety by developing a working system based on the hospital's service capability in treating orthopedic surgeries.
\end{abstract}

\section{METHODS}

A retrospective study was conducted involving $305 \mathrm{HCW}$. Data were collected on the application of a novel elective and emergency orthopedic surgery clinical pathway and scoring method based on questionnaires, and laboratory and radiographic chest examinations for several months to ensure the safety of HCW. HCW COVID-19 status was routinely checked as the indicator of HCW's safety.

\section{RESULTS}

Mean age of all patients was $47.0 \pm 22.41$ years. The screening process was done in a series of questionnaires and laboratory examinations, with the majority of patients ( 82 or $35.9 \%$ ) having a score of 0 . Patients with a score of 3 or more and testing positive for COVID-19 were immediately referred to a hospital having adequate facilities to prevent delays. There were 51 patients $(16.7 \%)$ with positive rapid test results, and 21 patients $(6.8 \%)$ with positive PCR tests. There were 4 (1.3\%) COVID-19 positive HCW.

\section{CONCLUSIONS}

Despite COVID-19 being a new threat, we have shown that developing an effective perioperative clinical pathway could eventually optimize healthcare worker safety.

Keywords: COVID-19, pandemic, screening, scoring, orthopedic surgery, healthcare workers
${ }^{1}$ Surabaya Orthopedic and

Traumatology Hospital, Department Of Orthopedic and Traumatology, Faculty of Medicine, Universitas Airlangga, Surabaya, Indonesia ${ }^{2}$ Medical Education Research and Staff Development Unit, Faculty of Medicine, Universitas Airlangga, Surabaya, Indonesia

\section{Correspondence:}

*Komang Agung Irianto

Surabaya Orthopedic and

Traumatology Hospital, Department Of Orthopedic and Traumatology,

Faculty of Medicine, Universitas Airlangga,

J1. Mayjend.Prof.Dr. Moestopo 6-8 Surabaya, 60286

Fax: +6231-5030406

Surabaya, Indonesia

Email: komang168@yahoo.com

ORCID ID: 0000-0001-6625-970X

Date of first submission, January 31 , 2021

Date of final revised submission, June 27, 2021

Date of acceptance, July 7, 2021

This open access article is distributed under a Creative Commons AttributionNon Commercial-Share Alike 4.0 International License

Cite this article as: Irianto KA, Adityawardhana T. Effective perioperative scoring in orthopedic surgery to prevent Covid-19 infection. Univ Med 2021;40:96-106. doi: 10.18051/UnivMed.2021.v40.99-109. 


\section{INTRODUCTION}

COVID-19 has been a catastrophe since 2019 and is classified as a global pandemic. ${ }^{(1)}$ Since March 2020 orthopedic surgeons have been facing a dilemma on whether or not to postpone elective surgeries; however, it is not easy to delay the emergency surgeries ${ }^{(2)}$ The pandemic also placed health-care workers (HCW) under an unprecedented strain, with more than 100,000 HCW deaths worldwide as of April 2020. ${ }^{(3)}$ As reported in Indonesia, in June $20202.6 \%$ of COVID-19 confirmed patients were Indonesian HCW (1,077 persons). ${ }^{(4)}$ At least $282 \mathrm{HCW}$ have died of COVID-19 ever since the start of the outbreak in Indonesia until November $10^{\text {th }}$ based on the statement of the Indonesian Medical Association (IDI). ${ }^{(5)}$ It has even been supposed that the actual number may have been much higher. ${ }^{(4)}$ Staff shortages in healthcare eventually became a significant conflict worldwide.

The pandemic has forced HCW to have more specific strategic deployment towards their clinical services as a response to their service demands in terms of both elective and emergency clinical services. ${ }^{(6)}$ Thus, the question arises as to the best medical practice for patients who suffer from both fracture and COVID-19 infection at the time of presentation. ${ }^{(1)}$ However, the COVID-19 screening is time-consuming, which delays surgery and may result in malunion, disability of an extremity, or a more serious complication. Therefore, maintaining a balance between adequate screening and timely surgery is essential for perioperative management of traumatic fractures..$^{(2)} \mathrm{A}$ standardized approach to perioperative COVID-19 testing is based on the patient's symptoms, and evaluating the risk of the procedure is crucial to ensure maximal safety of patients, their families, and HCW. A healthy HCW is an asset to the prolonged response in this pandemic and helps to reduce burnout. ${ }^{(7)}$

A previously published guideline was more focused on laboratory examination to predict
COVID-19 infection and was proven to be effective, ${ }^{(7)}$ while another guideline was issued to minimize delays and perioperative complications in orthopedic surgery but required several rooms and much space for proper COVID-19 screening, which we were unable to contemplate. ${ }^{(2)}$ Hospitals were then suggested to develop their own protocol based on their own resources and facilities to prevent COVID-19 and optimize what they had. ${ }^{(9)}$

The aim of this study is to ensure HCW safety with the application of novel clinical pathways based on questionnaires and laboratory and radiographic chest examinations in all orthopedic surgeries, including elective and emergency surgeries, and observe the effectiveness of the clinical pathway as indicated by the number of infected HCW which could be emulated by hospitals with limited space or resources.

\section{METHODS}

\section{Research design}

This was a retrospective cross-sectional study of the Orthopedic Division's medical records of patients that underwent surgeries from March 2020 to October 2020 at the Orthopedic \& Traumatology Hospital, Surabaya.

\section{Study subjects}

A total of 305 medical records from March 2020 to October 2020 had adequate data and were included in this study. Patients' clinical presentation, laboratory examination and radiographic examination were recorded, analyzed statistically and grouped.

\section{Instruments and orthopedic surgery classification}

Since April 2020, an emergency specialized task force at the Orthopedic \& Traumatology Hospital was tasked to develop instruments for a perioperative clinical pathway for personal protective equipment (PPE) to be used specifically for orthopedics surgery in the hospital. 
The task force agreed to focus more on the screening process to decide what type of PPE should be used in the surgery, with the goal of ensuring the safety of HCW, non-medical staff and patients.

The clinical pathway used in elective orthopedic surgery differs from that in emergency orthopedic surgery. Types of surgery were classified further, elective orthopedic surgery consisted of one-day surgery and non-emergency inpatient care, whereas emergency orthopedic surgery consisted of immediate, acute and urgent orthopedic cases. The surgery classification is described further in Table 1.

Table 1. Orthopedic surgery classification

\begin{tabular}{|c|c|c|c|c|c|}
\hline & Emergency & Acute & Urgent & $\begin{array}{c}\text { Non- } \\
\text { emergency } \\
\text { surgery } \\
\end{array}$ & $\begin{array}{l}\text { One day } \\
\text { surgery }\end{array}$ \\
\hline $\begin{array}{l}\text { Time to } \\
\text { surgery }\end{array}$ & $<24 \mathrm{hrs}$ & $24-48 \mathrm{hrs}$ & 48 hrs- 1 week & $>1$ week & \\
\hline Definition & $\begin{array}{l}\text { Life threatening/ } \\
\text { limb threatening. } \\
\text { Delay in } \\
\text { treatment } \\
\text { potentially } \\
\text { causes } \\
\text { disability or } \\
\text { mortality }\end{array}$ & $\begin{array}{l}\text { Delay in } \\
\text { treatment } \\
\text { may cause } \\
\text { severe infection, } \\
\text { disability or } \\
\text { mortality. } \\
\text { Estimate } \\
\text { significant } \\
\text { ongoing blood } \\
\text { loss }\end{array}$ & $\begin{array}{l}\text { Delay in } \\
\text { treatment } \\
\text { potentially causes } \\
\text { complications due } \\
\text { to } \\
\text { bleeding, } \\
\text { infection, } \\
\text { joint disruption } \\
\text { and } \\
\text { prolonged } \\
\text { immobilization }\end{array}$ & $\begin{array}{l}\text { Delay may not } \\
\text { cause } \\
\text { significant } \\
\text { morbidities/ } \\
\text { complication }\end{array}$ & $\begin{array}{l}\text { Without } \\
\text { hospital } \\
\text { admission }\end{array}$ \\
\hline \multirow[t]{4}{*}{ Case } & $\begin{array}{l}\text { Compartment } \\
\text { syndrome }\end{array}$ & $\begin{array}{l}\text { Femoral shaft } \\
\text { fracture }\end{array}$ & $\begin{array}{l}\text { Every type of } \\
\text { closed fracture } \\
\text { including spine } \\
\text { and } \\
\text { femoral shaft }\end{array}$ & $\begin{array}{l}\text { Every implant } \\
\text { removal surgery }\end{array}$ & $\begin{array}{l}\text { Every surger. } \\
\text { requiring } \\
\text { local } \\
\text { anaesthetic }\end{array}$ \\
\hline & Open fracture & Pelvic fracture & $\begin{array}{l}\text { Every acute } \\
\text { ligament and } \\
\text { tendon } \\
\text { injury whereas } \\
\text { end-to-end repair } \\
\text { is planned }\end{array}$ & $\begin{array}{l}\text { Total joint } \\
\text { arthroplasty }\end{array}$ & CTEV cases \\
\hline & AVN injury & $\begin{array}{l}\text { Multiple long } \\
\text { bone fracture }\end{array}$ & $\begin{array}{l}\text { Every pain } \\
\text { management } \\
\text { cases } \\
\text { that requires } \\
\text { inpatient care }\end{array}$ & $\begin{array}{l}\text { Curettage and } \\
\text { bone graft }\end{array}$ & \\
\hline & Dislocation & $\begin{array}{l}\text { Open degloving } \\
\text { injury }\end{array}$ & $\begin{array}{l}\text { Neglected } \\
\text { open fracture }\end{array}$ & $\begin{array}{l}\text { Minimally } \\
\text { invasive } \\
\text { spine surgery, } \\
\text { including } \\
\text { interspinous } \\
\text { device } \\
\text { insertion and } \\
\text { cervical disc } \\
\text { arthroplasty }\end{array}$ & \\
\hline
\end{tabular}


Table 1. continued

\begin{tabular}{|c|c|c|c|}
\hline $\begin{array}{l}\text { Acute } \\
\text { septic arthritis with } \\
\text { SIRS/sepsis }\end{array}$ & $\begin{array}{l}\text { Osteomyelitis with } \\
\text { subperiosteal } \\
\text { abscess }\end{array}$ & $\begin{array}{l}\text { Musculoskeletal } \\
\text { malignancies } \\
\text { amputation }\end{array}$ & $\begin{array}{l}\text { Every soft tissue } \\
\text { related case, } \\
\text { including tendon } \\
\text { lengthening and } \\
\text { tenotomy }\end{array}$ \\
\hline Crush injury & $\begin{array}{l}\text { Cellulitis with } \\
\text { SIRS/sepsis }\end{array}$ & $\begin{array}{l}\text { Osteomyelitis/TB } \\
\text { infection } \\
\text { debridement }\end{array}$ & $\begin{array}{l}\text { Every arthroscopic } \\
\text { procedure and } \\
\text { ligament } \\
\text { reconstruction }\end{array}$ \\
\hline $\begin{array}{l}\text { Damage control } \\
\text { surgeries }\end{array}$ & $\begin{array}{l}\text { Fracture dislocation } \\
\text { of } \\
\text { spine with cord } \\
\text { compression/ spinal } \\
\text { cord injury }\end{array}$ & $\begin{array}{l}\text { Musculoskeletal } \\
\text { abscess without } \\
\text { sepsis }\end{array}$ & $\begin{array}{l}\text { Acromioplasty } \\
\text { bursectomy }\end{array}$ \\
\hline \multirow[t]{4}{*}{$\begin{array}{l}\text { Suppurative } \\
\text { tenosynovitis }\end{array}$} & $\begin{array}{l}\text { Acute joint } \\
\text { infection } \\
\text { without sepsis }\end{array}$ & & Tumor excision \\
\hline & $\begin{array}{l}\text { Displaced } \\
\text { talar neck fracture }\end{array}$ & & $\begin{array}{l}\text { Bony and soft } \\
\text { tissue } \\
\text { reconstruction }\end{array}$ \\
\hline & Unstable SCFE & & $\begin{array}{l}\text { Every case } \\
\text { requiring } \\
\text { general anesthesia } \\
\text { that is not included } \\
\text { in emergency, } \\
\text { acute } \\
\text { or urgent group }\end{array}$ \\
\hline & $\begin{array}{l}\text { Closed fracture } \\
\text { dislocation }\end{array}$ & & \\
\hline
\end{tabular}

Abbreviation : AVN: avascular necrosis, also called osteonecrosis; SIRS: systemic inflammatory response syndrome; SCFE: slipped capital femoral epiphysis; CTEV: congenital talipes equinovarus

\section{Clinical pathway and scoring system for Covid-19 prevention}

This study combined, compared and was modeled after published guidelines from international and national suggestions. This eventually resulted in a scoring based on questionnaires and laboratory and radiographic chest examinations ${ }^{(7,8)}$ and perioperative assessment, ${ }^{(9-11)}$ the scoring was made by the hospital's service capability and is described in Table 2. These screening results will be taken into consideration, thus influencing the clinical pathway, surgical process, and level of personal protective equipment (PPE) for the surgery.
The clinical pathway was compared to previous published clinical pathways for emergency ${ }^{(2,8,12)}$ and elective orthopedic surgery. ${ }^{(13)}$ The proper PPE suggestions and training for $\mathrm{HCW}$ was also considered based on other publications. ${ }^{(9,14)}$ The clinical pathways for elective orthopedic surgery and emergency orthopedic surgery are described in Figures 1 and 2 , respectively.

\section{Healthcare workers (HCW) safety indicators}

The COVID-19 status of the HCW was routinely checked by means of the PCR test. It 
Table 2. Scoring based on questionnaire, laboratory and radiographic chest examination results

\begin{tabular}{|c|c|c|}
\hline & CRITERIA & SCORE \\
\hline $\begin{array}{l}\text { History } \\
\text { of last } \\
14 \text { days }\end{array}$ & $\begin{array}{l}\text { Fever }(>37.8) \\
\text { Cough / flu / sore throat } \\
\text { Breathing difficulty } \\
\text { Abdominal pain / diarrhea / nausea/ vomiting } \\
\text { Anosmia / cephalgia } \\
\text { Myalgia / arthralgia } \\
\text { Returned from abroad } \\
\text { Close contact with suspected or confirmed COVID-19 patients }\end{array}$ & $\begin{array}{l}0=\text { none } \\
1=\text { one of the criteria } \\
2=\geq 2 \text { criteria } \\
3=\text { close contact }(+)\end{array}$ \\
\hline $\begin{array}{c}\text { Clinical } \\
\text { Symptoms }\end{array}$ & $\begin{array}{l}\text { Fever }(>37.8) \\
\text { Cough/sneeze/sore throat } \\
\text { Breathing difficulty (Respiration Rate } \geq 24 \text { per minute) } \\
\text { Abdominal pain/diarrhea/nausea vomiting } \\
\text { Anosmia/cephalgia } \\
\text { Myalgia/arthralgia } \\
\text { Rhonchi / wheezing } \\
\text { Desaturation (SpO2 } \leq 95 \% \text { without oxygen supply) }\end{array}$ & $\begin{array}{l}0=\text { none } \\
1=\text { one of the criteria } \\
2=\geq 2 \text { criteria } \\
3=\text { desaturation }(+)\end{array}$ \\
\hline $\begin{array}{c}\text { Laboratory } \\
\text { Results }\end{array}$ & $\begin{array}{l}\text { Leukopenia }(<5000 / \mathrm{mm} 3) \text { or Leukocytosis }(>10000 / \mathrm{mm} 3) \\
\text { Lymphopenia }(\mathrm{ALC}<1500 / \mathrm{mm} 3) \\
\mathrm{NLR} \geq 5.8 \\
\mathrm{CRP}>10 \text { with normal procalcitonine } \\
\text { Thrombocytopenia of unknown origin } \\
\text { Increased BUN/serum creatinine or SGOT/SGPT of unknown } \\
\text { origin }\end{array}$ & $\begin{array}{l}0=\text { none } \\
1=\text { one of the criteria } \\
2=\geq 2 \text { criteria }\end{array}$ \\
\hline Radiology & $\begin{array}{l}\text { Consolidation or multifocal infiltrates observed on X-ray, } \\
\text { unilateral or bilateral }\end{array}$ & $\begin{array}{l}0=\text { none } \\
3=\text { positive }\end{array}$ \\
\hline
\end{tabular}

Abbreviations: ALC: absolute lymphocyte counts; NLR: neutrophil-to-lymphocyte ratio; CRP: C-reactive protein

became the indicator for the caregivers' safety and was routinely reported to evaluate the application of the clinical pathway. The HCW with positive results for COVID-19 were to be traced until the virus transmission was clearly pointed out.

\section{Data analysis}

Descriptive analysis was presented as frequency for categorical data and as mean $( \pm$ standard deviation) for numerical data.

\section{Ethical clearance}

This study was approved by the Health Research Ethics Commission of the Surabaya Orthopedic \& Traumatology Hospital under No. 01/PERS-EC/RSOT/V/2021.

\section{RESULTS}

A total of 305 medical records from March 2020 to October 2020 containing adequate data were included in this study. Around $55.8 \%$ of the records were of female patients and $44.2 \%$ of male patients. Mean age of all patients was 47.0 \pm 22.41 years.

Due to the continuous development of the screening process not all the records contained adequate data for all three parts of screening. Unfortunately only 228 medical records had adequate data for scoring and 289 medical records for orthopedic surgery classification. Thankfully, preoperative rapid tests were done to all orthopedics patients - with swab tests done accordingly. 


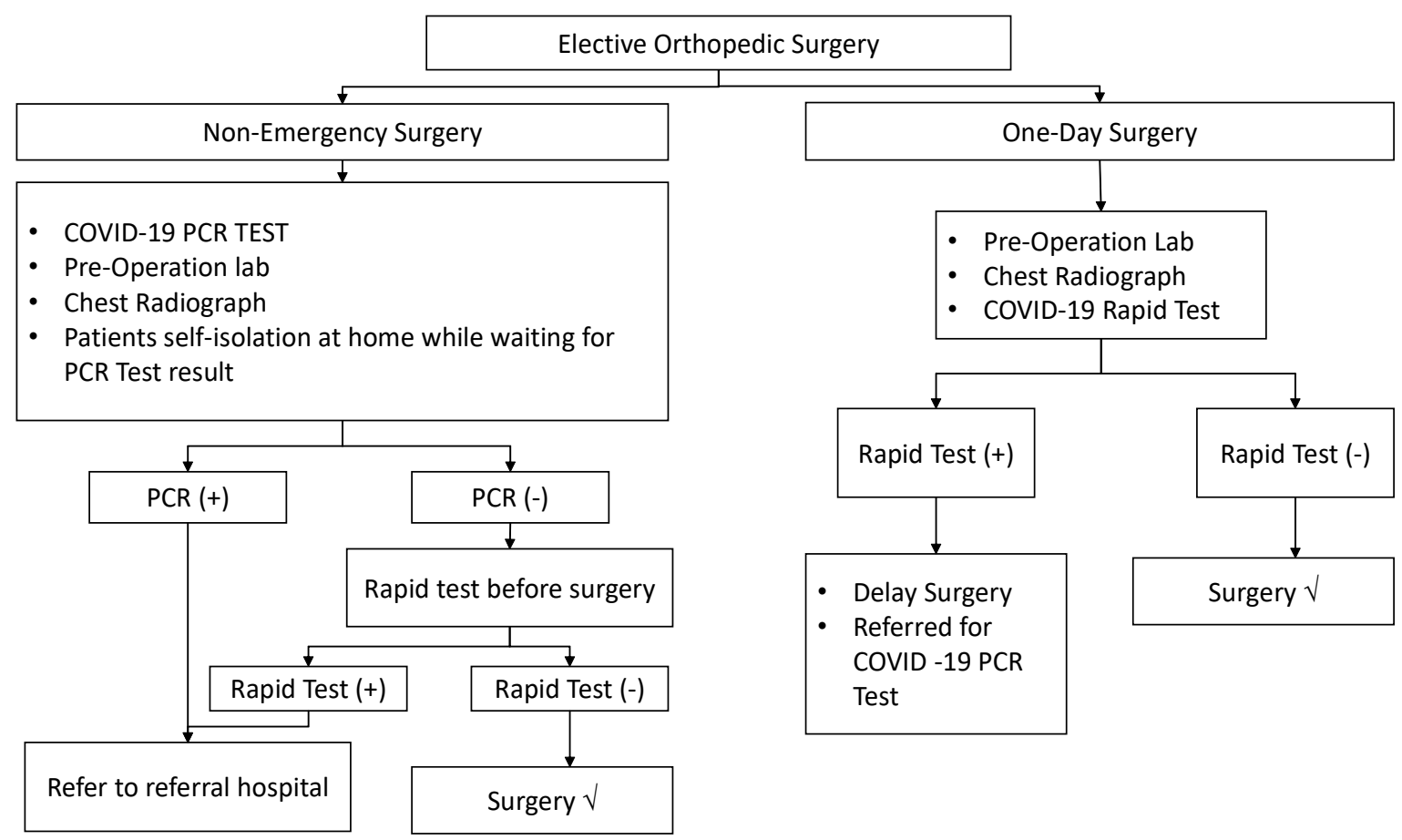

Figure 1. Elective orthopedic surgery clinical pathway

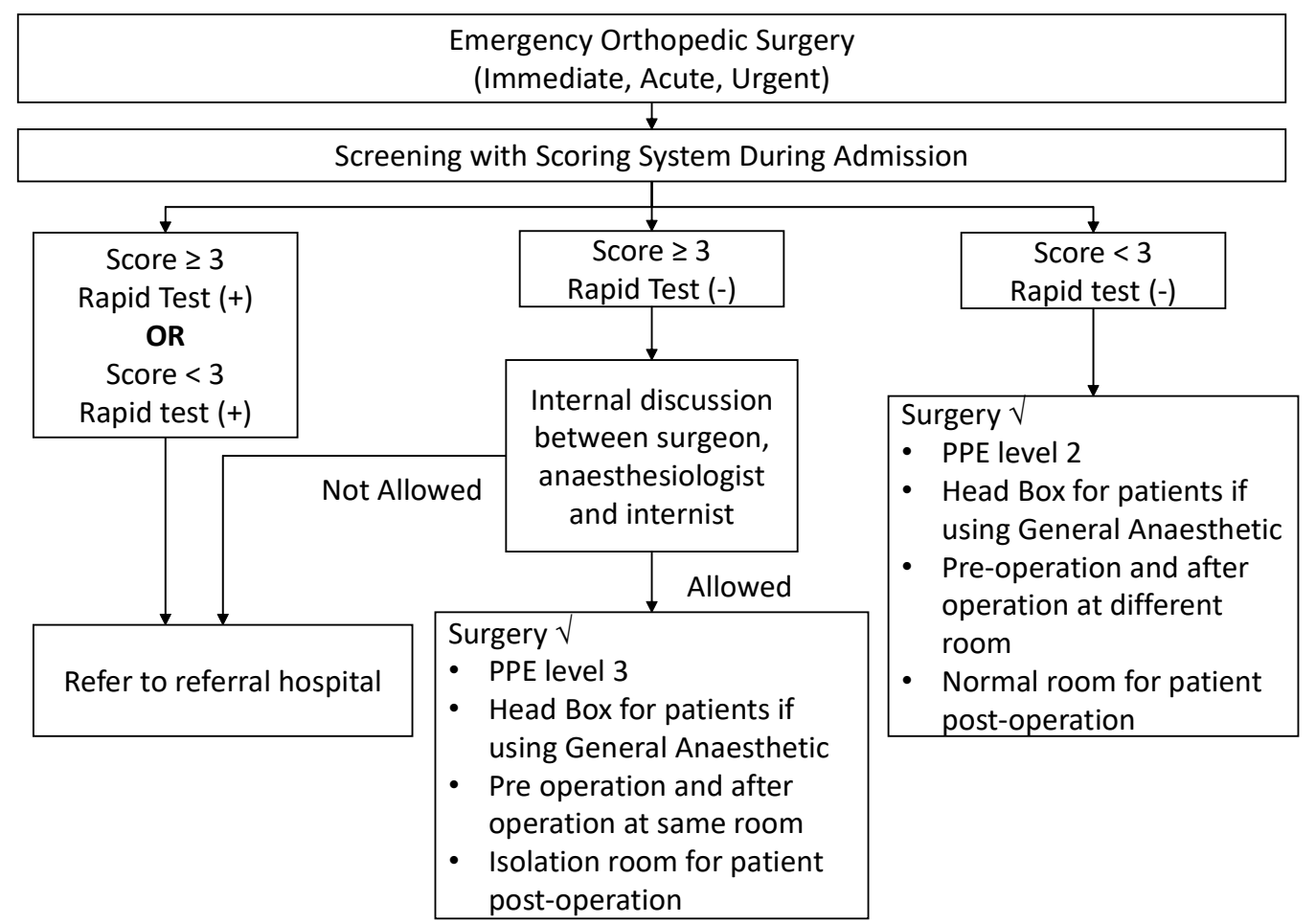

Figure 2. Emergency orthopedic surgery clinical pathway 
The screening process was done in a series of questionnaires and laboratory examinations and 82 patients (35.9\%) had a score of 0 . Due to the hospital's inability to provide a negative pressure operating theater, some patients having a score of 3 or more were immediately referred to a hospital with a negative pressure operating theater and were therefore not included in this research. The same procedure was followed for emergency patients that tested positive with the rapid test, which resulted in their data not being recorded properly to be included in this study. Overall, there were 51 patients $(16.7 \%)$ with positive rapid test results, and 21 patients $(6.8 \%)$ with positive PCR tests. Every patient who received a PCR test had already shown positive rapid test results.

Based on the surgery classification, the majority of 163 patients (56.4\%) underwent elective surgery and 86 patients $(29.7 \%)$ were classified into urgent surgery. The summary of COVID-19 screening score, patients' rapid test and swab test results; and surgery classification are presented in Table 3.

Table 3. Distribution of COVID-19 screening score, rapid and swab test and surgery classification

\begin{tabular}{cc}
\hline $\begin{array}{c}\text { COVID-19 screening score } \\
(\mathbf{n = 2 2 8})\end{array}$ & $\mathbf{n ~ ( \% )}$ \\
\hline Score of 0 & $82(35.9)$ \\
Score of 1 & $52(22.8)$ \\
Score of 2 & $89(39.1$ \\
Score of 3 & $4(1.7)$ \\
Score of 4 & $1(0.4)$ \\
Patients' rapid and swab test & \\
$(\mathrm{n}=305)$ & \\
Positive rapid test & $51(16.7)$ \\
Positive swab test & $21(6.8)$ \\
Surgery classification $(289)$ & $13(4.5)$ \\
One day surgery & $163(56.4)$ \\
Elective & $86(29.7)$ \\
Urgent & $3(1.1)$ \\
Acute & $24(8.3)$ \\
\hline Emergency
\end{tabular}

Routine checkup was done for the HCW There were four $(1.3 \%)$ hospital staff with COVID-19 positive results from March 2020 to October 2020, namely one anesthesiologist, one nurse, one lab officer and one marketing officer. After being traced, none of them had picked up the virus from the hospital environment. The anesthesiologist had caught it from a colleague at another hospital, the lab officer had it from family members, and the nurse had got the virus from her parents and had transmitted it to the marketing officer. There was no HCW that had caught the virus from the patients.

\section{DISCUSSION}

We were able to formulate the screening method, apply it to the clinical pathway for elective and emergency orthopedic patients, determine the time of surgery and refer the patient to avoid patient delays and to protect the $\mathrm{HCW}$. Unfortunately there were $4(1.3 \%)$ hospital staff with COVID-19. It is consistent with previous publications that using an easy-to-follow decision tree algorithm for the interventional platforms, early screening and triage, ${ }^{(15)}$ if implemented with proper training and self-discipline, HCW safety will be optimized. ${ }^{(11,12)}$ This is accomplished by minimizing perioperative complications and reducing delay of surgery ${ }^{(2,9)}$ as an alternative method based on hospital capabilities. ${ }^{(7)}$

Strict infection-control measures should be implemented to orthopedic patients particularly patients receiving surgical intervention. ${ }^{(1)}$ The importance of COVID-19 is undeniable and further steps have to be taken more carefully in order to not worsen the contamination that eventually may endanger the $\mathrm{HCW}^{(2)}$ It is the role of hospitals to develop protocol and workflow guidelines for diagnosis, management and precaution. ${ }^{(10)}$

The toughest problem is the emergency orthopedic surgery, where delays could bring significant harm to the patient or the outcome. ${ }^{(6)}$ Maintaining the balance between adequate screening and time-saving is essential, especially 
in emergency cases. ${ }^{(2)}$ By screening with a scoring system during admission the response time could be faster, the preparation could be started as soon as possible and the referral process could be started sooner if necessary. With proper training and discipline, this definitive scoring system and clinical pathway results in shortening of HCW's contact time with the patient, thus lowering the risk of COVID-19 transmission.

Due to the demand for elective surgeries, to stop them altogether for a long period of time is very unlikely. By March 2020 it was suggested to stop elective surgery altogether for a period of time and by then it was commonly agreed that the COVID-19 incidence in the hospital should decrease for at least 2 weeks before the elective surgery. ${ }^{(2)}$ The goal is to make the hospital stay as short as possible, as long as the roadmap of elective surgery is able to clearly sort out the problems, resumption seems possible. ${ }^{(6)}$ We applied the same approach as described in Figure 1 for elective surgery and in fact, most of our included medical records are about elective surgery. Granted the number of emergency surgeries included in this study could be higher but the fact that elective surgeries were done in high numbers suggests that it is possible to do. The key in our hospital was to be able to determine when to do the surgery, when to delay or to refer the patient because of the hospital's limitations.

E mergency specialized task forces were suggested to be assembled with the sole purpose of developing a perioperative scoring system based on the hospital's service capability because there is lack of proper and standardized scoring for COVID-19 screening, especially in surgical patients. ${ }^{(11)}$ A combination of the patient's history for the last 14 days, clinical findings, laboratory data, and radiological pattern based on the institutional or national policy are sufficient and are interpreted as a scoring based on published scoring guidelines. ${ }^{(7,8)}$ The scoring then suggested the appropriate management ${ }^{(9)}$ with appropriate $\mathrm{PPE}^{(11)}$ and perioperative preparation ${ }^{(11,14)}$ which can also be used for elective surgery. ${ }^{(13)}$ This was modeled into a clinical pathway for an easy-to-follow guideline as suggested. ${ }^{(12)}$

This was simplified into a scoring system that was proven to be effective, because HCW could make faster and more objective decisions that can reduce COVID-19 transmission by shortening contact time. With a proper clinical pathway, training and discipline preparation, the patient's management could be started sooner. It is very unfortunate that there were limitations with the study design being retrospective, the data were secondary data and this scoring only applied to orthopedic surgery. However, it was shown to be effective with only $4(1.3 \%) \mathrm{HCW}$ becoming COVID-19 positive and it can potentially be used in all other types of surgery, whether an emergency or elective surgery, with promising results. It is recommended that other hospitals develop a scoring system and risk assessment based on their capabilities and limitations with the sole purpose of protecting the patients and the $\mathrm{HCW}$ at least for emergency management during the COVID-19 pandemic. ${ }^{(15)}$

Ideally a negative pressure operating room should be provided for COVID-19 patients. But in some hospitals, including our own hospital where a negative pressure operating theater is not available, the surgeries had to be done in a positive pressure operating room. But not all orthopedic patients could be referred, especially with the hospital that has a negative pressure operating room being overloaded. Emergency cases still have to be treated if the hospital is capable and due to the demand for elective surgeries, to stop them altogether for a long period of time is very unlikely. ${ }^{(2,6)}$ Fortunately there were several guidelines, both international $(10,12,13)$ and national, ${ }^{(11)}$ that are also specific for orthopedic surgery ${ }^{(14)}$ on how to manage the surgical process without negative pressure operating room.

For the latter to succeed, the positive pressure system and the air conditioners have 
to be turned off. ${ }^{(11)}$ We used a portable highefficiency particulate air or HEPA machine to help maintain the proper air ventilation that is important to reduce the number of viruses in the circulating air. ${ }^{(11,13,14)}$ In the case of elective surgery, surgery can be performed in rooms at the normal positive pressure but there have to be modalities to maintain air ventilation. ${ }^{(14)}$ It is also recommended to minimize the number of people in the operating room, and if possible the patient's recovery in the post-operative phase should also be done in the operating room. ${ }^{(11,14)}$ Hospitals have to develop their own screening system based on their capabilities. ${ }^{(13)}$ To be able to decide which patient to operate on and which to refer is essential to reduce COVID-19 transmission both inside and outside the operating room.

On top of all, HCW protection should become a priority. While there is a shortage of staff, protecting HCW has to be prioritized while the HCW themselves have to adapt to the new situation. ${ }^{(17)}$ With social distancing not essentially effective in controlling COVID-19 incidence, ${ }^{(18)}$ the stressor among $\mathrm{HCW}$ in dealing with the possibility of a prolonged pandemic could cause burnouts. ${ }^{(19)}$ Supplies of personal protective equipment (PPE) may be limited, and unfortunately this requires a more restricted access to PPE to make sure it is being used properly. ${ }^{(10)}$ Routine testing and tracing are suggested in the hospital environment because the infection rate is still high, but unfortunately the number of PCR swab tests for COVID-19 is still limited. Proper management to maintain the balance between screening needs and swab test supplies is required. The HCW or other hospital staff who have been proved positive should be isolated and their contacts traced. ${ }^{(16)}$ Proper training and self-discipline once again has to be applied with the already existing clinical pathways and regulations. ${ }^{(10)}$

Fortunately we were able to routinely check the HCW. Four of them were swab positive from March 2020 to October 2020 and only two of the four (an anesthesiologist and a nurse) were in close contact with patients, whereas the other two (a lab officer and a marketing officer) were not. After tracing was done as suggested, ${ }^{(16,17)}$ it was found that the anesthesiologist caught it from a colleague in another hospital, the lab officer had it from family members, and the nurse got the virus from her parents and transmitted it to the marketing officer. There were no HCW that caught the virus from the patients. HCW with a positive swab test were to be self-quarantined for at least 2 weeks and if showing signs and symptoms were to be admitted to hospital.

These results may be an indicator that the use of a proper clinical pathway, proper scoring for immediate screening and proper surgery regulation combined with proper training and discipline may minimize the chance of HCW contracting COVID-19 from their patients. In addition, with the possibility of economic impact on primary and universal healthcare the simple alterations to our daily practice may benefit the $\mathrm{HCW}$ and their patients. ${ }^{(20)}$

The limitation of this study is that this is a retrospective review study and all the data for this study are secondary data. The score has also to be validated in larger populations.

Hopefully the screening methods, clinical pathways and results of this research could be a model for hospital service that can be used for all orthopedic surgery interventional platforms and trigger hospitals in underdeveloped and developing countries to devise their own easy-to-use algorithms.

\section{CONCLUSION}

The COVID-19 pandemic has forced rapid development of novel hospital guidelines across a spectrum of clinical environments, including orthopedics. Despite COVID-19 being a new threat, we have shown that developing an effective perioperative clinical pathway could eventually optimize healthcare worker safety. 


\section{CONFLICT OF INTEREST}

The authors declared no potential conflicts of interest with respect to the research, authorship and/or publication of this article.

\section{FUNDING}

The authors received no financial support for the research, authorship and/or publication of this article.

\section{CONTRIBUTORS}

Both KAI and TA were involved in conception and design of study, data acquisition, drafting of the manuscript and revising the manuscript. Both authors have read and approved the final manuscript.

\section{REFERENCES}

1. Mi B, Chen L, Xiong Y, Xue H, Zhou W. Liu G. Characteristics and early prognosis of COVID-19 infection in fracture patients. J Bone Joint Surg Am 2020;102:750-8. doi: 10.2106/JBJS.20.00390.

2. Meng Y, Leng K, Shan L, et al. A clinical pathway for pre-operative screening of COVID-19 and its influence on clinical outcome in patients with traumatic fractures. Int Orthop 2020; 44:1549-55. doi:10.1007/s00264-020-04645-3.

3. Black JR, Bailey C, Przewrocka J, et al. COVID-19: the case for health-care worker screening to prevent hospital transmission. Lancet 2020; 395:1418-20. doi: 10.1016/S0140-6736(20)30917-X.

4. World Health Organization Indonesia. Coronavirus Disease 2019 (COVID-19) Situation Report-13. Jakarta: World Health Organization Indonesia;2020.

5. Wong JS, Cheung KM. Impact of COVID-19 on orthopaedic and trauma service: an epidemiological study. JBJS 2020;102:e80. doi: 10.2106/JBJS.20.00775.

6. Geng Ramos G, Cronin JA, Heitmiller E, et al. Implementation and expansion of a preoperative COVID 19 testing process for pediatric surgical patients. Pediatr Anesth 2020;30:952-3. doi: 10.1111/pan.13963.

7. Vieceli T, Oliveira Filho CM, Berger M, et al. A predictive score for COVID-19 diagnosis using clinical, laboratory and chest image data. Braz J
Infect Dis 2020;24:343-8. doi: 10.1016/j.bjid.2020. 06.009 .

8. Song CY, Xu J, He JQ, Lu YQ. COVID-19 early warning score: a multi-parameter screening tool to identify highly suspected patients. MedRxiv 2020. doi: https://doi.org/10.1101/2020.03.05. 20031906.

9. Tang G, Chan AK. Perioperative management of suspected/confirmed cases of COVID-19. Anaesth Tutor Week 2020;19:1-3.

10. Arif SK, Muchtar F, editors. Manajemen perioperatif pasien Covid-19. Makassar: Perhimpunan Dokter Anestesiologi dan Terapi Intensif Indonesia (PERDATIN);2020.

11. Senapathi TG, Ryalino C, Wiryana M, et al. Perioperative safety during Covid-19 pandemic: a review article. Bali J Anesth 2020;4:8. doi: 0.4103/ BJOA.BJOA 8320.

12. Forrester JD, Nassar AK, Maggio PM, Hawn MT. Precautions for operating room team members during the COVID-19 pandemic. J Am Coll Surg 2020;230:1098-101. doi: 10.1016/j.jamcollsurg. 2020.03.030.

13. Parvizi J, Gehrke T, Krueger CA, et al. Resuming elective orthopaedic surgery during the COVID19 pandemic: guidelines developed by the International Consensus Group (ICM). J Bone Joint Surg Am 2020;102:1205-12. doi: 10.2106/ JBJS.20.00844.

14. Perrone G, Giuffrida M, Bellini V, et al. Operating room setup: how to improve health care professionals safety during pandemic COVID-19a quality improvement study. J Laparoendoscopic Advanced Surgical Techniques 2021;31:85-9. doi: 10.1089/lap.2020.0592.

15. Manoochehry S, Saboori F, Faraji M, et al. Coronavirus disease 2019: a revolution in biological triage in the emergency setting. Univ Med 2020;39:212-23. doi: 10.18051/UnivMed.2020. v39.212-223.

16. Hidayat R, Aini N, Ilmi AF, Azzahroh F, Giantini A. Test, trace, and treatment strategy to control COVID-19 infection among hospital staff in a COVID-19 referral hospital in Indonesia. Acta Med Indones 2020;52:206-13.

17. Liu Q, Luo D, Haase JE, et al. The experiences of health-care providers during the COVID-19 crisis in China: a qualitative study. The Lancet Global Health 2020;8:e790-8. doi: 10.1016/S2214109X(20)30214-X.

18. Alnur RD, Veruswati M, Asyary A. Has it done properly? The difference between before and after social distancing's policy implementation in controlling Covid-19 in Jakarta, Indonesia. InE3S Web of Conferences 2020;202:12031. doi: e3sconf/202020212031. 
19. Windarwati HD, Ati NA, Paraswati MD, et al. Stressor, coping mechanism, and motivation among health care workers in dealing with stress due to the COVID-19 pandemic in Indonesia. Asian J Psychiat 2021;56:102470.j.ajp.2020. 102470.
20. Yusuf E. Primary health care for all: lessons from its failure to achieve its goal and COVID-19. Univ Med 2021;40:1-2. doi: 10.18051/UnivMed.2021. v40. 1-2. 